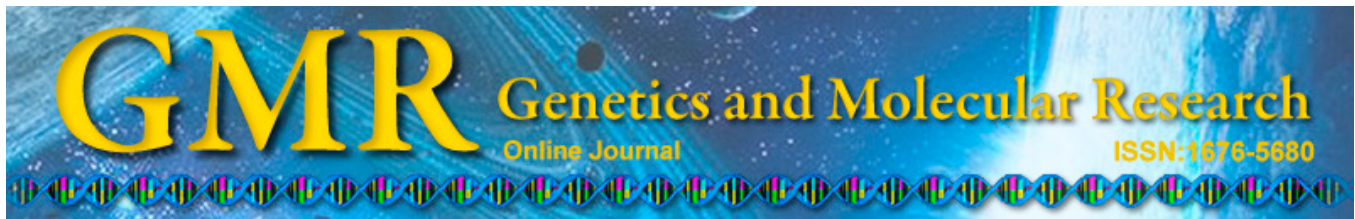

\title{
Indirect selection of industrial tomato genotypes that are resistant to spider mites (Tetranychus urticae)
}

\author{
J.E. Baier ${ }^{1}$, J.T.V. Resende ${ }^{2}$, M.V. Faria ${ }^{2}$, K. Schwarz ${ }^{3}$ and L. Meert ${ }^{2}$ \\ ${ }^{1}$ NUNHEMS, Estação de Pesquisa e Desenvolvimento NUNHEMS, \\ Uberlânida, MG, Brasil \\ ${ }^{2}$ Departamento de Agronomia, Universidade Estadual do Centro-Oeste, \\ Guarapuava, PR, Brasil \\ ${ }^{3}$ Divisão de Produção Agroindustrial e de Alimentos, \\ Centro de Energia Nuclear na Agricultura, Universidade de São Paulo, \\ Piracicaba, SP, Brasil \\ Corresponding author: J.T.V. Resende \\ E-mail: jresende@unicentro.br / jvresende@uol.com.br
}

Genet. Mol. Res. 14 (1): 244-252 (2015)

Received June 12, 2014

Accepted November 11, 2014

Published January 16, 2015

DOI http://dx.doi.org/10.4238/2015.January.16.8

\begin{abstract}
Acyl sugars present in the tomato Solanum lycopersicum 'LA-716' accession confer good levels of resistance to arthropod pests. The objective of the present study was to select $\mathrm{F}_{2}$ plants from the interspecific cross Solanum pennellii 'LA-716' x Solanum lycopersicum 'Redenção' to assess resistance to spider mites (Tetranychus urticae) based on the leaf acyl sugar content and repellence tests. Four genotypes were selected with high leaflet acyl sugar content (RVTA-2010 pl\#31, RVTA-2010 pl\#75, RVTA-2010 pl\#83, and RVTA-2010 pl\#94), and an additional three genotypes with low acyl sugar content were also selected (RVTA-2010 pl\#33, RVTA-2010 pl\#39, and RVTA-2010 $\mathrm{pl}$ \#73). The results from the in vivo tests used to confirm the selection of plants resistant to mites indicated that the genotypes with high acyl sugars content did not differ from the resistant parent LA-716. The
\end{abstract}


negative correlation between acyl sugar content and the distance run by the mite along the leaflet surface confirmed the association between high and low allelochemical content and resistance. The medium degree of dominance (MDD) was estimated (MDD $=-0.83$ ), indicating that the high acyl sugar content was due to incomplete dominance of a recessive allele. A value of $81.85 \%$ was found for the broad sense heritability estimate, which suggests that most among-plant variation in the $\mathrm{F}_{2}$ generation is genetically based. Furthermore, 0.69 genes were estimated, which presumably confirms monogenic inheritance. Thus, indirect selection was an efficient method used to obtain industrial tomato plants that are resistant to spider mites.

Key words: Solanum lycopersicum; Solanum pennellii; Allelochemicals; Plant breeding; Genetic resistance

\section{INTRODUCTION}

Chemical pest control in tomato crops requires excessive applications of widespectrum products. In addition to high production costs (Embrapa, 2009), the improper use of agricultural pesticides damages the environment, harms human health, and encourages the appearance of more aggressive biotypes. Considering these aspects, the use of resistant cultivars is the safest and most viable alternative for pest management. Tetranychus urticae is considered one of the most important species of spider mite pest worldwide because it has a large number of hosts (Moraes and Flechtmann, 2008). Spider mites have high potential for damage to tomato crops, and they can cause heavy losses to the producers.

Sources of resistance to tomato pests have been identified in species of Solanum, which have the potential for use in genetic breeding programs to develop resistant cultivars (Gonçalves Neto et al., 2010; Maluf et al., 2010; Maciel et al., 2011). For instance, resistance obtained from $S$. pennellii has been associated with the presence of allelochemicals called acyl sugars. These sugars confer a sticky aspect to the leaf surface that serves as a natural trap, interferes in oviposition and feeding, and has a deleterious effect on the development of certain arthropod stages (Gillardón et al., 2001; Resende et al., 2009). The introduction of resistance to spider mites in S. lycopersicum tomato genotypes from a wild species (S. pennellii) is an effective way to obtain cultivars with high acyl sugar content in the leaflet and consequently a good resistance level (Maciel et al., 2011). In the tomato breeding programs conducted in Brazil that are used to obtain pest resistant cultivars, indirect selection predominates the development of genotypes with high allelochemical leaflet contents associated with resistance (Resende et al., 2008). In general, indirect selection for high allelochemical content has led to increased pest resistance more efficiently than direct selection techniques. Studies emphasize the correlation between the concentration and characterization of each allelochemical present in the wild accessions and their respective control level of specific pests. However, there is little research related to tomato genotypes that are destined for industrial processing. This emphasizes the importance of breeding programs to obtain tomato cultivars for industrial processing that are resistant to the main pests. The objective of the present study was to select $\mathrm{F}_{2}$ plants with high acyl sugar content from the interspecific cross S. lycopersicum L. 'Redenção' x S. pennellii 'LA-716' to assess resistance to spider 
mites (T. urticae), and to confirm the heredity of acyl sugar content variation.

\section{MATERIAL AND METHODS}

The experiment was conducted in 2010 and 2011 in Guarapuava, PR, Brazil

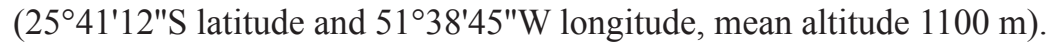

The $\mathrm{F}_{1}$ and $\mathrm{F}_{2}$ generations were obtained from the interspecific cross between S. lycopersicum 'Redenção' and S. pennellii 'LA716'. Redenção is a commercial cultivar developed by the Pernambuco Agronomic Institute - IPA for industrial processing, and is resistant to geminivirus and tospovirus (Ferraz et al., 2003). LA716 is a wild accession with high acyl sugar content, and it is a source of pest resistance. In a greenhouse, 496 plants were cultivated in pots: 34 S. pennellii plants (parental with high acyl sugar content), 26 S. lycopersicum plants (parental with low acyl sugar content), $40 \mathrm{~F}_{1}$ generation plants, and $396 \mathrm{~F}_{2}$ plants.

A colorimetric assessment was carried out in the laboratory 50 days after transplantation to pots to quantify the acyl sugar content in the leaflets. Quantification was based on six leaf disc samples collected from the upper third of the plant in triplicate, and the methodology was based on that proposed by Resende et al. (2002a). Plants selected from the $\mathrm{F}_{2}$ population exhibited high acyl sugar content, which was comparable or superior to the mean content found in $S$. pennellii leaflets. Furthermore, $\mathrm{F}_{2}$ plants with low acyl sugar content were also selected, and the content was comparable or lower than the average content found in S. lycopersicum leaflets.

\section{Genetic parameters of the acyl sugar content}

The mean and variance values of acyl sugar content of S. lycopersicum and S. pennellii in the $\mathrm{F}_{1}$ and $\mathrm{F}_{2}$ generations were calculated and used to estimate the following parameters according to Ramalho et al. (1993): genetic variance $\left(\hat{\sigma}_{G}^{2}\right)$, broad sense heritability $\left(h_{b}^{2}\right)$, and the environmental variance $\left(\hat{\sigma}_{E}^{2}\right)$ (i.e., the variance of the 'Redenção' cultivar).

The main parameters were estimated following the methodology of Mather and Jinks (1984), which uses the weighted minimum square method where the inverse ratio of the variance of the mean of each population serves as the weight. The parameters $\mathrm{m}$, [a], and [d] were estimated from the available population means (parents, $\mathrm{F}_{1}$, and $\mathrm{F}_{2}$ ). The chi-square test was conducted to validate the genetic model assumed. In the case of non-rejection of the model, the medium degree of dominance (MDD) was estimated: $\mathrm{MDD}=[\mathrm{a}] /[\mathrm{d}]$. The expressions by Burton (1951) were used to estimate the number of genes.

\section{Bioassays of the genotypes selected with spider mites (T. urticae)}

The responses of the genotypes selected for comparing acyl sugar content were used to assess $T$. urticae infestation. Resistance was quantified following the repellence test proposed by Western and Snyder (1990). The spider mites were collected from naturally infected beans (Phaseolus vulgaris L.), and were identified in an entomology laboratory.

The four $\mathrm{F}_{2}$ genotypes selected with high acyl sugar content and the three $\mathrm{F}_{2}$ genotypes with low acyl sugar content were assessed. The parents, $S$. pennellii (high acyl sugar content) and $S$. lycopersicum (low acyl sugar content), and the $\mathrm{F}_{1}$ generation (intermediate acyl sugar 
content) were used as controls. In the pre-flowering phase, similar sized opened leaflets were removed from the upper third of the plants selected. Each leaflet was fixed with a $9 \mathrm{~mm}$ diameter drawing pin in the central region, with the adaxial surface upwards, on a sheet of white paper on a styrofoam block. Leaflets representing each genotype were placed randomly on the styrofoam, and four replications were made. The trials were conducted in a chamber at $16^{\circ} \pm 1{ }^{\circ} \mathrm{C}$ with 64 $\pm 4 \%$ relative humidity. Ten female spider mites were transferred to the center of each drawing pin using a fine brush. The mean distance run by the spider mites $(\mathrm{mm})$ on the surface of each leaflet from the center of the drawing pin were measured after 20, 40, and $60 \mathrm{~min}$ of exposure. Those that remained on the drawing pin were recorded as zero. Short distances run by spider mites on the upper surface of the leaflet indicated greater levels of resistance.

The data were analyzed using analysis of variance (ANOVA) tests, and the means were compared using the Tukey test at 5\% probability. Differences among the treatments with high and low acyl sugar content were estimated to obtain better inferences regarding the relationship between acyl sugar content and resistance levels. The correlation estimates between the acyl sugar content and the distances run by the spider mites on the leaflet surface were tested with the Student $t$-test. The Genes computer package was also used (Cruz, 2001).

\section{RESULTS AND DISCUSSION}

\section{Acyl sugar content quantification}

The mean and variance values for the acyl sugar content of the plants in the assessed populations are shown in Table 1.

\begin{tabular}{|c|c|c|c|}
\hline Genotype & No. of plants evaluated & Mean content of acyl sugar $\left(\mathrm{nmol} / \mathrm{cm}^{2}\right)$ & Estimated variance $\left(\mathrm{nmol} / \mathrm{cm}^{2}\right)$ \\
\hline S. lycopersicum & 26 & 58.43 & 103.82 \\
\hline S. pennellii & 34 & 109.15 & 643.55 \\
\hline Generation $F_{1}$ & 40 & 62.83 & 85.67 \\
\hline Generation $\mathrm{F}_{2}$ & 396 & 71.47 & 572.02 \\
\hline
\end{tabular}

The wild accession, S. pennellii, exhibited medium acyl sugar content that was measured at $109.15 \mathrm{nmol} / \mathrm{cm}^{2}$, which is approximately 1.87 -fold greater than $S$. lycopersicum $\left(58.44 \mathrm{nmol} / \mathrm{cm}^{2}\right)$. The mean acyl sugar content of the $\mathrm{F}_{1}$ generation plants $\left(62.84 \mathrm{nmol} / \mathrm{cm}^{2}\right)$ was lower than that of the parents and similar to that found in S. lycopersicum. Comparable results were obtained by Resende et al. (2002a) where S. lycopersicum had medium acyl sugar content $\left(28.26 \mathrm{nmol} / \mathrm{cm}^{2}\right)$ that was lower than S. pennellii $\left(63.75 \mathrm{nmol} / \mathrm{cm}^{2}\right)$, and the $\mathrm{F}_{1}$ generation exhibited an average of $32.87 \mathrm{nmol} / \mathrm{cm}^{2}$.

The estimated value of the broad sense heritability for acyl sugar content was $81.85 \%$ (Table 2). This value indicates that most of the variation among plants in the $\mathrm{F}_{2}$ generation was genetically based, with the possibility of selective gains of individuals with high acyl sugar content in segregant generations. The broad sense heritability estimate of $48 \%$ was reported by Resende et al. (2002b), which shows the difficulty of environmental control with an assessment system that not only includes the plant, but also the arthropod pest. The broad sense 
heritability estimates of the allelochemical contents in interspecific crossings were high in the studies conducted by Barbosa and Maluf (1996) for 2-tridecanona $\left(h^{2}=0.60\right)$ and Freitas et al. (2002) for zingiberene $\left(h^{2}=0.67\right)$, and these estimates indicate that most of the factors responsible for allelochemical presence are heritable. Therefore, it is expected that they could be successfully used as characteristics of indirect selection for pest resistance.

\begin{tabular}{lc} 
Table 2. Estimates of genetic parameters for the average acyl sugar content in the leaflets of $\mathrm{F}_{2}$ generation \\
tomato plants from the cross between Solanum lycopersicum and S. pennellii. \\
\hline Parameter & Estimate \\
\hline Phenotypic variance & 572.0222 \\
Environmental variance & 103.8255 \\
Genotypic variance & 468.1966 \\
Broad-sense heritability (\%) & 0.8185 \\
Number of genes & 0.6900 \\
\hline
\end{tabular}

The number of genes estimated was 0.69 (Table 2) under the assumption that a single genetic locus is responsible for the genetic control of the acyl sugar content in the interspecific S. lycopersicum and S. pennellii cross.

The number of genes (1.36) estimated by Resende et al. (2002b) and confirmed by Gonçalves et al. (2007) suggested that monogenic heredity is involved in the genetic control of this characteristic. The MDD value was estimated at -0.82 . The additive dominant model was not rejected by the chi-square test (Table 3), revealing the presence of a recessive locus in S. pennellii with incomplete dominance that is responsible for the high acyl sugar content. Similar results were obtained by Resende et al. (2002b) who reported an MDD value of -0.74 . Because of the incomplete dominance of the allele that controls the acyl sugar content, Maciel et al. (2011) obtained hybrids that were resistant to arthropod pests by crossing lines with high and low acyl sugar content.

Table 3. Estimates of mean components and the chi-square test of validity using the Mather and Jinks (1984) model of interspecific tomato crossing (Solanum lycopersicum x S. pennellii) based on the acyl sugar content.

\begin{tabular}{lccc}
\hline Generation & Mean (observed) & Mean (estimated) & Deviation \\
\hline S. lycopersicum & 58.4358 & 57.9082 & 0.5276 \\
S. pennellii & 109.1529 & 106.6038 & 2.5491 \\
$\mathrm{~F}_{1}$ & 62.8380 & 62.2613 & 0.5767 \\
$\mathrm{~F}_{2}$ & 71.4786 & 72.3025 & 0.8239 \\
$\mathrm{~m}$ & & 82.2510 & 1.0471 \\
[d] & & -19.9897 & 1.2461 \\
[a] & & 24.3528 & 1.5115 \\
Medium degree of dominance MDD = [d] / [a] & & -0.8200 & $0.9800^{\text {ns }}$ \\
\hline$\chi^{2}$
\end{tabular}

${ }^{\text {ns Not significant. }}$

\section{Reaction of tomato genotypes to infestation with the $T$. urticae}

The mean distances run by the spider mites on the leaflet surfaces of the selected $\mathrm{F}_{2}$ genotypes with high acyl sugar content (RVTA-2010 pl\#31, RVTA-2010 pl\#75, RVTA-2010 $\mathrm{pl} \# 83$, and RVTA-2010 pl\#94) did not differ significantly from the distances run on the surface of the leaflets of the $S$. pennellii genotypes $(\mathrm{P}>0.05)$ (Table 4). 
Table 4. Average distances traveled by mites (Tetranychus urticae) after 20, 40, and $60 \mathrm{~min}$ of exposure on the adaxial surface of Solanum lycopersicum, S. pennellii, and $\mathrm{F}_{1}$ and $\mathrm{F}_{2}$ generation leaflets from plants selected. Estimates of the contrasts between genotypes and the correlations of medium distances with the level of acyl sugar are shown.

\begin{tabular}{|c|c|c|c|c|}
\hline \multirow[t]{2}{*}{ Genotype } & \multirow[t]{2}{*}{$\begin{array}{l}\text { Acyl sugar } \\
\left(\mathrm{nmol} / \mathrm{cm}^{2}\right)\end{array}$} & \multicolumn{3}{|c|}{$\begin{array}{l}\text { Distances }(\mathrm{mm}) \text { traveled by } \\
\text { mites on leaflet surface }\end{array}$} \\
\hline & & $20 \mathrm{~min}$ & $40 \mathrm{~min}$ & $60 \mathrm{~min}$ \\
\hline S. lycopersicum & 58.44 & $20.00^{\mathrm{b}}$ & $25.68^{\mathrm{c}}$ & $26.75^{\mathrm{e}}$ \\
\hline S. pennellii & 109.15 & $1.05^{\mathrm{a}}$ & $0.63^{\mathrm{a}}$ & $0.38^{\mathrm{a}}$ \\
\hline $\mathrm{F}_{1}$ & 62.84 & $4.75^{\mathrm{a}}$ & $2.13^{\mathrm{a}}$ & $4.23^{\mathrm{ab}}$ \\
\hline RVTA-2010pl\#33 (= low 1) & 40.92 & $4.63^{\mathrm{a}}$ & $8.40^{\mathrm{ab}}$ & $11.13^{\mathrm{bcd}}$ \\
\hline RVTA-2010pl\#39 (= low 2) & 42.17 & $8.80^{\mathrm{ab}}$ & $12.35^{\mathrm{b}}$ & $13.80^{\mathrm{d}}$ \\
\hline RVTA-2010pl\#73 (= low 3) & 41.75 & $6.30^{\mathrm{a}}$ & $8.53^{\mathrm{ab}}$ & $12.30^{\mathrm{cd}}$ \\
\hline RVTA-2010pl\#31 (= high 1$)$ & 196.34 & $3.00^{\mathrm{a}}$ & $4.75^{\mathrm{ab}}$ & $4.28^{\mathrm{ab}}$ \\
\hline RVTA-2010pl\#75 (= high 2) & 196.81 & $1.13^{\mathrm{a}}$ & $2.78^{\mathrm{a}}$ & $3.40^{\mathrm{ab}}$ \\
\hline RVTA-2010pl\#83 (= high 3$)$ & 221.54 & $1.10^{\mathrm{a}}$ & $3.30^{\mathrm{ab}}$ & $3.00^{\mathrm{a}}$ \\
\hline RVTA-2010pl\#94 (= high 4) & 179.89 & $2.65^{\mathrm{a}}$ & $4.43^{\mathrm{ab}}$ & $4.68^{\mathrm{ab}}$ \\
\hline \multicolumn{5}{|l|}{ Contrasts of interest } \\
\hline $\mathrm{C}_{1}=S$. lycopersicum vs high $\mathrm{F}_{2}$ genotypes & & $-18.03^{*}$ & $-21.86^{*}$ & $-22.91 *$ \\
\hline $\mathrm{C}_{2}=$ High $\mathrm{F}_{2}$ genotypes $v s$ low $\mathrm{F}_{2}$ genotypes & & -4.60 & -5.95 & $-8.57 *$ \\
\hline \multicolumn{5}{|l|}{ Linear correlations } \\
\hline Distances traveled by mites $v s$ acyl sugar contents in $\mathrm{F}_{2}$ genotypes & & -0.60 & -0.59 & $-0.69 * 1$ \\
\hline
\end{tabular}

${ }^{a}$ Means followed by the same letter do not differ from each other according to the Tukey test $(\mathrm{P}=0.05)$. ${ }^{\text {Significant }}$ based on the $\mathrm{F}$ test $(\mathrm{P}=0.05)$ and ${ }^{1}$ significant based on the Student $t$-test $(\mathrm{P}=0.05)$.

In general, it was evident that high acyl sugar content in the leaflet inhibited spider mite walking on the leaflet surface (contrasts $\mathrm{C} 1$ and $\mathrm{C} 2$ in Table 4). Genotypes selected for high acyl sugar content inhibited spider mite locomotion on the leaflet surface after 40 and 60 min exposures compared to low content genotypes. These results were consistent with the conclusions of Resende et al. (2002b), Gonçalves et al. (2006), and Maluf et al. (2010) where acyl sugars were the main mechanisms of resistance after 20 and 40 min exposures; however, the differences among these genotypes were significant after $60 \mathrm{~min}$ (Table 4).

The methodology of Western and Snyder (1990) was used by Gonçalves et al. (2006) who reported that higher zingiberene content was associated with high levels of resistance to spider mites in populations derived from the S. lycopersicum and Lycopersicon hirsutum var. hirsutum cross. Moreover, using the same methodology, Resende et al. (2002b, 2008), observed correlations between the acyl sugar content and spider mite resistance in materials from the interspecific $S$. lycopersicum and $S$. pennellii cross. The values of the linear correlations (Table 4) indicate that the distances run by the spider mites on the selected genotypes were inversely proportional to the acyl sugar content present in the leaflets. After $60 \mathrm{~min}$ of exposure, the distances run on the surface of the leaflets of the $\mathrm{F}_{2}$ selected genotypes were significant, and they were negatively correlated with the acyl sugar content $(-0.69)$. Therefore, the increase in resistance to spider mites was an indirect response to selection for high acyl sugar content.

In the insect-plant interaction, the growth of phytophage insect populations is generally inhibited by biochemical and morphological characteristics of the host plant, which affect insect performance or metabolism and reduce the level of harm caused to the plant (Lara, 1991). In this sense, in the first 20 and $40 \mathrm{~min}$ of exposure, the distances run by the spider mites were not significant because of two factors. The first is the host recognition process, in which the mite identifies the host by test sucking after receiving suitable stimuli. The second is the acceptance or rejection of the host, depending on the compounds found (Lara, 1991). The genotypes that exhibited high acyl sugar content on the leaflet surface presumably released 
the chemical compound that paralyzed spider mite movement, which resulted in significant differences after $60 \mathrm{~min}$ of exposure.

Over time, the spider mites displayed the paralyzing effects on their movements along the surface of the high acyl sugar content leaflets and on S. pennellii, thus proving resistance to $T$. urticae. In genotypes selected for low acyl sugar content and in $S$. lycopersicum, the spider mites found no movement difficulty. According to several studies, the acyl sugars act as antibiosis-type resistance mechanisms for many arthropod pests, revealing indirect genetic gains for resistance when direct selection is used for high leaflet acyl sugar content (Goffreda et al., 1989; Hawthorne et al., 1992; Rodrigues et al., 1993; Juvik et al., 1994; Liedl et al., 1995; Resende et al., 2002b). Studies on other allelochemicals (2-tridecanona and zingiberene) and the control of tomato arthropod pests and resistant sources present in wild Solanum accessions have also been reported (Maluf et al., 1997, 2001; Labory et al., 1999; Gonçalves et al., 1998; Freitas et al., 2002; Azevedo et al., 2003). The acyl sugar content in tomato genotypes derived from S. lycopersicum and S. pennellii are sufficiently efficient in increasing the resistance levels to T. urticae, and may explain the acceptable resistance levels found in the $F_{1}$ generation. Saeidi et al. (2007) attributed resistance to the spider mites found in heterozygote $F_{1}$ genotypes to other factors besides the acyl sugars also present in S. pennellii. However, the fact that S. pennellii presents a high level of resistance to spider mites compared to genotypes with high low or intermediate acyl sugar content indicates that other factors present in S. pennellii may also contribute to the high levels of resistance to spider mites in this accession.

The method used to determine the acyl sugars was satisfactory in distinguishing the genotypes selected for high and low acyl sugar content. Studies have been conducted via the indirect selection of resistant plants and by using a colorimetric method to quantify the acyl sugars in the tomato leaflet, which is cheap and relatively easy to apply (Resende et al., 2002a). The results reinforced previous studies (Goffreda et al., 1989; Hawthorne et al., 1992; Rodrigues et al., 1993; Juvik et al., 1994; Liedl et al., 1995; Resende et al., 2006; Saeidi et al., 2007; Silva et al., 2009; Maluf et al., 2010) where acyl sugars derived from S. pennellii were mostly associated with high pest resistance. Therefore, selection for high acyl sugar content indeed increased pest resistance compared to the genotypes selected for low acyl sugar content.

Although they are not the only factors that confer pest resistance to S. pennellii, acyl sugars may indeed be an important component of resistance. Furthermore, they are inherited simply (Gonçalves et al., 2007), and high acyl sugar content can be easily introduced in genotypes in industrial tomato breeding programs. The genetic gains for resistance to arthropod pests were shown when direct selection was made for high acyl sugar content.

\section{CONCLUSIONS}

The results obtained in current study showed the following: 1 . The direct selection method for high acyl sugar content in plants of the $\mathrm{F}_{2}$ generation was efficient in obtaining plants resistant to the T. urticae spider mite (RVTA-2010 pl\#31, RVTA-2010 pl\#75, RVTA$2010 \mathrm{pl} \# 83$, and RVTA-2010 pl\#94). 2. Average distances run by the T. urticae spider mite were inversely proportional to the acyl sugar content present in the leaflets. 3. Resistance to the spider mite is conditioned by a single gene, and the action of a recessive allele with incomplete dominance results in high acyl sugar content. 4 . The causes of among plant variation in the $\mathrm{F}_{2}$ generation are genetically based. 


\section{ACKNOWLEDGMENTS}

We thank CAPES and Araucaria Foundation for postgraduate scholarship, and CNPq for research financial support and for the undergraduate scholarship.

\section{REFERENCES}

Azevedo SM, Faria MV, Maluf WR and Oliveira ACB (2003). Zingiberene-mediated resistance to the South American tomato pinworm derived from Lycopersicon hirsutum var. hirsutum. Euphytica 134: 347-351.

Barbosa LV and Maluf WR (1996). Heritability of 2-tridecanone-mediated arthropod resistance in an interspecific segregating generation of tomato. Bras. J. Genet. 19: 465-468.

Burton GW (1951). Quantitative inheritance of pearl millet (Pennisetum glaucum). Agron. J. 43: 409-416.

Cruz CD (2001). Programa Genes: Aplicativo Computacional em Genética e Estatística (Versão Windows). Universidade Federal de Viçosa, Viçosa.

EMBRAPA (Empresa Brasileira de Pesquisa em Agropecuária) (2009). Sistemas de Produção. Available at [http:// sistemasdeproducao.cnptia.embrapa.br/FontesHTML/Tomate/TomateIndustrial_2ed/]. Accessed February 22, 2014.

Ferraz E, Resende LV, Lima GSA and Silva MCL (2003). Redenção: nova cultivar de tomate para a indústria resistente a geminivírus e tospovírus. Hortic. Bras. 21: 578-580.

Freitas JA, Maluf WR, Cardoso MG and Gomes LAA (2002). Inheritance of foliar zingiberene contents and their relationship to trichome densities and whitefly resistance in tomatoes. Euphytica 127: 275-287.

Gillardón E, Pocovi M, Hernández C and Collavino G (2001). Papel da 2-tridecanona e dos tricomas glandulares tipo VI na resistência do tomateiro a Tuta absoluta. Pesq. Agropec. Bras. 36: 929-933.

Goffreda JC, Mutschler MA, Avé DA, Tingey WM, et al. (1989). Aphid deterrence by glucose esters in glandular trichome exudate of the wild tomato, Lycopersicon pennellii. J. Chem. Ecol. 15: 2135-2147.

Gonçalves LD, Maluf WR, Cardoso MG and Resende JTV (2006). Zingibereno, tricomas foliares e sua ação na repelência a Tetranychus evansi em tomateiros derivados do cruzamento Lycopersicon esculentum $\mathrm{x}$ L. hirsutum var. hirsutum. Pesq. Agropec. Bras. 41: 267-273.

Gonçalves LD, Maluf W, Cardoso MG and Gomes LAA (2007). Herança de acilaçúcares em genótipos de tomateiro provenientes de cruzamento interespecífico. Pesq. Agropec. Bras. 42: 699-705.

Gonçalves MIF, Maluf WR, Gomes LAA and Barbosa LV (1998). Variation of 2-tridecanone levels in tomato plant leaflets and resistance to two mite species (Tetranychus sp.). Euphytica 104: 33-38.

Gonçalves Neto AC, Silva VF, Maluf WR and Maciel GM (2010). Resistência à traça-do-tomateiro em plantas com altos teores de acilaçúcares nas folhas. Hortic. Bras. 28: 203-208.

Hawthorne DJ, Shapiro JA, Tingey WM and Mutschler MA (1992). Trichome-borne and artificially applied acylsugars of wild tomato deter feeding and ovoposition of the leafminer Liriomyza trifolii. Entomol. Exp. Appl. 65: 65-73.

Juvik JA, Shapiro JA, Young TE and Mutschler MA (1994). Acylglucoses from wild tomatoes alter behavior and reduce growth and survival of Helicoverpa zea and Spodoptera exigua (Lepidoptera: Noctuidae). J. Econ. Entomol. 87: 482-492.

Labory CRG, Santa-Cecília LV, Maluf WR and Cardoso MD (1999). Seleção indireta para teor de 2-tridecanona em tomateiros segregantes e sua relação com a resistência à traça-do-tomateiro. Pesq. Agropec. Bras. 34: 733-740.

Lara FM (1991). Princípios de Resistência de Plantas a Insetos. Ícone, São Paulo.

Liedl BE, Lawson DM, Shapiro JA and White KK (1995). Acylsugars of wild tomato Lycopersicon pennellii alters settling and reduces oviposition of Bemisia argentifolii (Homoptera: Aleyrodidae). J. Econ. Entomol. 88: 742-748.

Maciel GM, Maluf WR, Silva VF and Gonçalves Neto AC (2011). Híbridos pré-comerciais resistentes a Tuta absoluta obtidos de linhagem de tomateiro rica em acilaçúcares. Hortic. Bras. 29: 151-156.

Maluf WR, Barbosa LV and Santa-Cecília LVC (1997). 2-Tridecanone-mediated mechanisms of resistance to the South American tomato pinworm Scrobipalpuloides absoluta (Meyrick, 1917) (Lepidoptera-Gelechiidae) in Lycopersicon spp. Euphytica 93: 189-194.

Maluf WR, Campos GA and Cardoso MG (2001). Relationships between trichome types and spider mite (Tetranychus evansi) repellence in tomatoes with respect to foliar zingiberene contents. Euphytica 121: 73-80.

Maluf WR, Maciel GM, Gomes LAA and Cardoso MG (2010). Broad-spectrum arthropod resistance in hybrids between high- and low-acylsugar tomato lines. Crop Sci. 50: 439-450.

Mather K and Jinks JL (1984). Introdução à Genética Biométrica. Sociedade Brasileira de Genética, Ribeirão Preto.

Moraes GJ and Flechtmann CHW (2008). Manual de Acarologia: Acarologia Básica e Ácaros de Plantas Cultivadas no 
Brasil. Holos, Ribeirão Preto.

Ramalho MAP, Santos JB and Zimmerman MJ (1993). Genética Quantitativa em Plantas Autógamas. UFG, Goiânia.

Resende JTV, Cardoso MG, Maluf WR and Santos CD (2002a). Método colorimétrico para quantificação de acilaçúcar em genótipos de tomateiro. Cienc. Agrotec. 26: 1204-1208.

Resende JT, Maluf WR, Cardoso M, Nelson DL, et al. (2002b). Inheritance of acylsugar contents in tomatoes derived from an interspecific cross with the wild tomato Lycopersicon pennellii and their effect on spider mite repellence. Genet. Mol. Res. 1: 106-116.

Resende JTV, Maluf WR, Faria MV and Pfann AZ (2006). Acylsugars in tomato leaflets confer resistance to the South American tomato pinworm, Tuta absoluta Meyr. Sci. Agric. 63: 20-25.

Resende JTV, Maluf WR, Cardoso MG and Faria MV (2008). Resistance of tomato genotypes with high level of acylsugars to Tetranychus evansi Backer \& Pritchard. Sci. Agric. 65: 31-35.

Resende JTV, Maluf WR, Cardoso MG and Gonçalves LD (2009). Resistance of tomato genotypes to the silverleaf whitefly mediated by acylsugars. Hortic. Bras. 27: 345-348.

Rodrigues AE, Tingey WM and Mutschler MA (1993). Acylsugars of Lycopersicon pennelli deter settling and feeding of the green peach aphid (Homoptera: Aphididae). J. Econ. Entomol. 86: 34-49.

Saeidi Z, Mallik B and Kulkarni RS (2007). Inheritance of glandular trichomes and two-spotted spider mite resistance in cross Lycopersicon esculentum 'Nandi' and L. pennellii 'LA2963'. Euphytica 154: 231-238.

Silva VF, Maluf WR, Cardoso MG and Gonçalves Neto AC (2009). Resistência mediada por aleloquímicos de genótipos de tomateiro à mosca-branca e ao ácaro-rajado. Pesq. Agropec. Bras. 44: 1262-1269.

Western PA and Snyder JC (1990). Thumbtack biossay: a quick method of measuring plant resistance to two-spotted spider mites (Acari: Tetranychidae). J. Econ. Entomol. 83: 501-504. 